http://dx.doi.org/10.1016/i.dsr.2010.03.009

(c) 2010 Elsevier Ltd All rights reserved.

\title{
Uncoupled transport of chlorofluorocarbons and anthropogenic carbon in the subpolar North Atlantic
}

\author{
Marta Álvarez ${ }^{a,{ }^{*}}$, Claire Gourcuff ${ }^{\mathrm{b}}$ \\ a IMEDEA (CSIC-UIB), Miquel Marqués 21, 07190 Esporles, Spain \\ ${ }^{\mathrm{b}} \mathrm{CNES}$, Ifremer, Plouzané, France \\ *: Corresponding author : Marta Álvarez, email address : marta.alvarez@co.ieo.es
}

\begin{abstract}
:
Chlorofluorocarbon (CFC) 11 and 12 transports across the transoceanic World Ocean Circulation Experiment (WOCE) A25 section in the subpolar North Atlantic are derived from an inverse model using hydrographic and ADCP data (Lherminier et al., 2007). CFC and anthropogenic carbon ( $\left.C_{\mathrm{ANT}}\right)$ advective transports contrary to expected are uncoupled: $C_{\text {ANT }}$ is transported northeastwards $\left(82 \pm 39 \mathrm{kmol} \mathrm{s}^{-1}\right)$ mainly within the overturning circulation, while CFC-11 and CFC-12 are transported southwestwards $\left(-24 \pm 4\right.$ and $-11 \pm 2 \mathrm{~mol} \mathrm{~s}^{-1}$, respectively) as part of the large-scale horizontal circulation. The main reason for this uncoupled behaviour is the complex CFC vs. $C_{\mathrm{ANT}}$ relation in the ocean, which stems from the contrasting temperature relation for both tracers: more $C_{\mathrm{ANT}}$ dissolves in warmer waters with a low Revelle factor, while CFC's solubility is higher in cold waters. These results point to $C_{\mathrm{ANT}}$ and CFC having different routes of uptake, accumulation and transport within the ocean, and hence: $C_{\mathrm{ANT}}$ transport would be more sensitive to changes in the overturning circulation strength, while CFC to changes in the East Greenland Current and Labrador Sea Water formation in the Irminger Sea. Additionally, $C_{\text {ANT }}$ and CFCs would have different sensitivities to circulation and climate changes derived from global warming as the slowdown of the overturning circulation, increase stratification due to warming and changes in wind stress.
\end{abstract}

Keywords: Anthropogenic carbon; CFC; Advective transports; Subpolar North Atlantic 


\section{Introduction}

The North Atlantic subpolar gyre is dominated by advection of recently formed water masses carrying a large burden of man-made tracers, anthropogenic $\mathrm{CO}_{2}\left(\mathrm{C}_{\mathrm{ANT}}\right)$ (Sabine et al., 2004) and chlorofluorocarbons (CFC) (Willey et al., 2004). CFC are biologically inert and entirely anthropogenic, so their distribution provides information about rates and pathways of water mass ventilation (England and Maier-Reimer, 2001) and also $C_{\text {ANT }}$ accumulation (McNeil et al., 2003; Hall et al., 2002). However, the patterns of $C_{\text {ANT }}$ and CFC accumulation differ regionally because of differences in their atmospheric histories, temperature dependence and air-sea gas exchange equilibration time (Körtzinger et al., 1999; McNeil et al., 2003; Tanhua et al., 2009). Previous studies in the North Atlantic dealt with the relation between $\mathrm{C}_{\mathrm{ANT}}$ and CFC distributions and their temporal evolution (e.g., Körtzinger et al., 1999; Macdonald et al., 2003; Tanhua et al., 2006), C ANT $_{\text {AN }}$ transport (e.g., Álvarez et al., 2003; Macdonald et al., 2003; Rosón et al., 2003) and CFC derived formation rates (e.g., Smethie and Fine, 2001; Rhein et al., 2002), but none have jointly studied their transports and the controlling mechanisms.

The present work revises the $\mathrm{C}_{\mathrm{ANT}}$ transport across the World Ocean Circulation Experiment (WOCE) A25 line (Figure 1) published in Álvarez et al. (2003), with the new circulation patterns proposed by Lherminier et al. (2007, Lh07 hereinafter), where the circulation initially proposed in Álvarez et al. (2002, A02 hereinafter) is further constrained with ADCP data. Using the revisited circulation (Lh07), CFC transports are calculated for the first time. Additionally, the mechanisms behind CFC and $\mathrm{C}_{\mathrm{ANT}}$ transports are analysed.

\section{Data and Methods}

The WOCE A25 line was sampled in August-September 1997 crossing the subpolar North Atlantic from the Iberian Peninsula to Cape Farewell (Figure 1). Data from this line (Bacon, 1998) were used to infer volume and biogeochemical transports and budgets in the North Atlantic (Álvarez et al., 2002, 2003, 2004). In this work, the volume transport is taken from Lh07 where the initial geostrophic velocity field across section A25 was constrained using ADCP data from Greenland to station $46\left(45^{\circ} 47^{\prime} \mathrm{N}-24^{\circ} 39^{\prime} \mathrm{W}\right)$ and salt conservation for the whole section. Briefly, the main differences between the first derived (A02) and the revisited (Lh07) circulation across A25 are: a stronger East Greenland Current (EGC) flowing southwestward near Cape Farewell and a weaker southwestward bottom flux in the Charlie Gibbs Fracture Zone (CGFZ) (see Table 2 in Lh07).

The $C_{A N T}$ estimation along the WOCE A25 section is described and discussed in Álvarez et al. (2003). $C_{\text {ANT }}$ is estimated using a modified version of the $\Delta C^{*}$ method (Gruber et al., 1996) derived by Perez et al. (2002) for the North Atlantic where:

$C_{A N T}=T I C-A O U / R_{C}-1 / 2 \cdot\left(\Delta A_{T}+A O U / R_{N}\right)-T_{I C}{ }^{e q \pi}$

where AOU (Apparent Oxygen Utilization, being the saturated minus measured oxygen) is calculated using the oxygen saturation equation from Benson and Krause (UNESCO, 1986). $R_{C}=1.45 \pm 0.17$ and $R_{N}=10.6 \pm 0.7$ (Anderson and Sarmiento, 1994). $\Delta A_{T}$ (alkalinity variation from preformed conditions) is calculated as $\Delta A_{T}=\left(2 \cdot I O R / R_{C}-1 / R_{N}\right) \cdot A O U$, where IOR is the inorganic to organic carbon decomposition ratio as in equation 12 by Pérez et al. (2001). $\mathrm{TIC}^{\mathrm{eq} \pi}$ is the inorganic carbon in equilibrium with the pre-industrial atmosphere, estimated from the sample potential temperature and salinity, the time-independent preformed alkalinity, the pre-industrial atmospheric $\mathrm{CO}_{2}$ level (Neftel et al., 1994) and, the $\mathrm{CO}_{2}$ constants from Mehrbach et al. (1973). Pérez et al. (2002) estimated the $\mathrm{CO}_{2}$ disequilibrium for water masses formed in the North Atlantic to be small and within the uncertainty of the 
$\mathrm{C}_{\mathrm{ANT}}$ estimation method. Therefore, according to their work no disequilibrium term is included in this formulation. Using a Gaussian uncertainty propagation analysis, the estimated uncertainty in $C_{A N T}$ is $7 \mu \mathrm{mol} \mathrm{kg}{ }^{-1}$ (Álvarez et al., 2003). Depths between the surface and 130 dbar are homogenized in $\mathrm{C}_{\mathrm{ANT}}$ to avoid biases due to biological activity. $\mathrm{C}_{\mathrm{ANT}}$ values at 130 dbar, below the seasonal thermocline, are taken for this upper layer, between the surface and $130 \mathrm{dbar}$.

CFC analysis details are given in Bacon (1998): CFC analyses were carried out using gas chromatography (Bullister and Weiss, 1988) with some modifications done by Boswell and Smythe-Wright (1996). Duplicate measurements were made and showed precision of CFC tracers to be within the WOCE requirements, less than $1 \%$ or $0.005 \mathrm{pmol} \mathrm{kg}{ }^{-1}$, whichever is greater. CFC data have been compiled in several studies (Rhein et al., 2002; LeBel et al., 2008; Tanhua et al., 2008) but no work centres particularly on the A25 CFC data.

In order to understand the mechanisms leading to the volume and tracer transport, we have separated the geostrophic fluxes into three components (A02): a barotropic term due to the net transport across the line; a baroclinic term due to the horizontally averaged vertical structure; and finally, a horizontal term due to the residual flow after the barotropic and baroclinic components have been subtracted, which is associated with the horizontal variations about the baroclinic profile. The baroclinic and horizontal components have no net volume flow, and in this case the barotropic one as well. The barotropic transport includes the Ekman layer, the net barotropic water column transport across the line and the bottom triangles. The baroclinic and horizontal transports are respectively associated with the meridional overturning circulation and the large-scale gyre circulation including smaller scale eddies. To quantify these components for the volume and tracer transport, the orthogonal velocity (v) and tracer fields (C), are separated into a section-averaged value $(\langle\bar{v}\rangle$ and $\langle\overline{\mathrm{C}}\rangle$, respectively), a baroclinic profile of zonally averaged values at each depth $(<\mathrm{v}\rangle(\mathrm{z})$ and $<C>(z)$ ), and the deviations from zonal averages (anomalies) for each pair of stations and depth $\left(v^{\prime}(x, z)\right.$ and $\left.C^{\prime}(x, z)\right)$. Hence,

$$
\mathrm{v}=<\overline{\mathrm{v}}>+<\mathrm{v}>(\mathrm{z})+\mathrm{v}^{\prime}(\mathrm{x}, \mathrm{z}) \quad \mathrm{C}=<\overline{\mathrm{C}}>+<\mathrm{C}>(\mathrm{z})+\mathrm{C}^{\prime}(\mathrm{x}, \mathrm{z})
$$

The corresponding transports are calculated as:

1. Barotropic component:

$$
\rho_{\mathrm{S}, \mathrm{T}, \mathrm{P}} \cdot<\overline{\mathrm{v}}>\cdot<\overline{\mathrm{C}}>\cdot \int \mathrm{L}(\mathrm{z}) \mathrm{dz}
$$

2. Baroclinic component:

$$
\int \rho_{\mathrm{S}, \mathrm{T}, \mathrm{P}} \cdot<\mathrm{v}>(\mathrm{z})<\mathrm{C}>(\mathrm{z}) \cdot \mathrm{L}(\mathrm{z}) \mathrm{dz}
$$

3. Horizontal component:

$$
\int \rho_{\mathrm{S}, \mathrm{T}, \mathrm{P}} \cdot \mathrm{v}^{\prime}(\mathrm{x}, \mathrm{z}) \cdot \mathrm{C}^{\prime}(\mathrm{x}, \mathrm{z}) \cdot \mathrm{dz} \cdot \mathrm{dx}
$$

where $L(z)$ is the width of the section at each depth and $\int L(z) d z$ is the area of the section. The volume transport is expressed in Sverdrups $\left(10^{6} \mathrm{~m}^{3} \mathrm{~s}^{-1}\right)$, so density is not introduced in its calculations. The $C_{\text {ANT }}$ and CFC transports are given in $\mathrm{kmol} \mathrm{s}^{-1}\left(10^{3} \mathrm{~mol} \mathrm{~s}^{-1}\right)$ and $\mathrm{mol} \mathrm{s}^{-1}$, respectively. 


\section{Results}

\subsection{Tracer distributions}

Most of the main water masses found in the North Atlantic were detected along the A25 section (Álvarez et al., 2004): ENACW, SAIW, LSW, MW, DSOW, ISOW and LDW (acronyms in Figure 2). The section also crosses two important currents: the northern branch of the North Atlantic Current (NAC) (Figure 2a) over the west Mid-Atlantic Ridge (MAR, around $50^{\circ} \mathrm{N}$ ), and the EGC near Cape Farewell.

Several models and back-calculation techniques assume that any increase in CFC implies a corresponding increase in $\mathrm{C}_{\mathrm{ANT}}$, but this is not the case at least in the subpolar North Atlantic (Tanhua et al., 2006). A conservative tracer with exponentially increasing surface concentration reaches a "transient steady state" after a time significantly larger than the surface growth timescale ( 60 years for $\mathrm{C}_{\mathrm{ANT}}$ ) for a one dimensional system (Keeling and Bolin, 1967; Gammon et al., 1982). The concept states that, after a period significantly longer than the exponential growth time scale of the tracer, the vertical tracer profiles reach transient steady state and have a constant "shape". The tracer concentrations at all depths then increase at a rate that is proportional to the surface layer increase.

According to Tanhua et al. (2006) $\mathrm{C}_{\mathrm{ANT}}$ is increasing equally over time throughout the water column of the North Atlantic while CFCs are not, CFCs are entering the ocean more in a pulse like. This fact is reflected in the general smooth vertical $C_{\text {ANT }}$ penetration along the section (Figure $2 b$ ) while CFC-11 presents some inflection points as the LSW maximum tongue on the eastern MAR and the bottom maximum values associated with DSOW (Figure 2c).

Along with the different atmospheric histories and ocean chemistry, CFC and $\mathrm{C}_{\text {ANT }}$ correlate differently with temperature (Figure 3a\&b): warm upper waters south of the NAC (see Figure 2a) dissolve higher $\mathrm{C}_{\mathrm{ANT}}$ as they have a lower Revelle factor ${ }^{1}$. On the contrary, CFC-11 dissolves easier in cold waters north of the NAC. The relationship between CFC-11 and $\mathrm{C}_{\text {ANT }}$ (Figure 3c) shows two groups of data: samples north and south of the NAC $\left(\sim 50^{\circ} \mathrm{N}\right)$, for the same CFC-11 concentration samples north of the NAC contain less $\mathrm{C}_{\mathrm{ANT}}$. If the partial pressure of CFC-11 (pCFC-11 = CFC-11 /solubility, function by Warner and Weiss (1985)) is calculated to eliminate the effect of variable temperature and salinity, a practically linear relationship appears between pCFC-11 and $\mathrm{C}_{\mathrm{ANT}}$ (Figure $3 \mathrm{~d}$ ).

\subsection{Transports and mechanisms}

The total $\mathrm{C}_{\mathrm{ANT}}$ transport across section $\mathrm{A} 25$ with the revisited circulation in Lh07 amounts to $82 \pm 39 \mathrm{kmol} \mathrm{s}^{-1}$, not significantly different from the previous result $116 \pm 125 \mathrm{kmol} \mathrm{s}^{-1}$ (Álvarez et al., 2003). In both results the uncertainty in the $C_{\text {ANT }}$ estimate (about $7 \mu \mathrm{mol} \mathrm{kg}^{-1}$ ) is included in the final uncertainty estimation, along with the uncertainty in the volume transport estimate which is the main source of uncertainty. The $\mathrm{C}_{\text {ANT }}$ uncertainty transport given in Álvarez et al. (2003) is overestimated, the worst situation is considered as explained in the Appendix of the former work. If the inverse method considered in Lh07 is set with the constraints in $A 02$, the $C_{A N T}$ uncertainty is reduced, being $128 \pm 67 \mathrm{kmol} \mathrm{s}^{-1}$. Despite the circulation, Lh07 or A02, the $\mathrm{C}_{\mathrm{ANT}}$ transport across the WOCE A25 section is consistently northeastwards. The main difference between the Lh07 and A02 circulation affects the deep water transport, with a lower $\mathrm{C}_{\mathrm{ANT}}$ burden. As $\mathrm{C}_{\mathrm{ANT}}$ is mainly transported within the NAC in upper waters (see below), changes in the deep water circulation have a lower impact.

Contrary to what it is expected, tracer transports are uncoupled: $\mathrm{C}_{\mathrm{ANT}}$ transport is northeastward while CFC are transported southwestward at rates of $-24 \pm 4$ and $-11 \pm 2 \mathrm{~mol} \mathrm{~s}^{-1}$

\footnotetext{
${ }^{1}$ Revelle or buffer factor, is the ratio of the instantaneous fractional change in the seawater partial pressure of $\mathrm{CO}_{2}$ with regard to the fractional change in total $\mathrm{CO}_{2}$ dissolved (Revelle and Suess, 1957; Broecker et al 1979); waters with a low Revelle factor, warm waters, are more efficient in dissolving $\mathrm{CO}_{2}$ for a given change in atmospheric $\mathrm{CO}_{2}$.
} 
for CFC-11 and -12 , respectively (Table 1 ). The following paragraphs explore the reasons behind these results.

Figure 4 shows the volume and tracer transports by density layers and geographical regions (regions and layers shown in Figure 2a). These transports are integrated northwestwards, from the Iberian Peninsula to Cape Farewell. Figure 4a shows that the main northeastward volume transport occurs within the upper layer and associated with the NAC (region 5), while the EGC (region 10) contributes with a high southwestward transport affecting the whole water column. The differences between the previous (A02) and revisited (Lh07) circulation are the following: in the upper layer the EGC southwestward transport (region 10) is increased; in the intermediate layer the total transport has not changed, but regional differences appear, the northeastward transport within the CGFZ (region 6) is increased, the southwestward transport in the west Reykjanes Ridge (region 8) is reduced and the southwestward transport in the EGC is increased; in the deep layer the southwestward transport over the CGFZ (region 6) is reduced in the revisited circulation while in the Iberian Basin (region 2) the northestward LDW transport is reduced.

The $\mathrm{C}_{\mathrm{ANT}}$ is mainly transported northeastwards within the NAC upper and intermediate layers (Figure 4b), while the EGC partially compensates this northeastward transport. The revisited $\mathrm{C}_{\mathrm{ANT}}$ transport is reduced compared to Álvarez et al. (2003) because the southwestward transport in the EGC intermediate layer is increased (Figure 4b). CFC-11 and -12 transports (Figure 4c \& d) are very similar, the northeastward upper layer transport is surpassed by the southwestward intermediate, deep and bottom transports. The main northeastward transport occurs within the NAC in the upper and intermediate layers, but is largely compensated in the upper EGC and surpassed in the intermediate EGC; deep and bottom transports mainly occur in the EGC, being southwestward. So, $C_{\text {ANT }}$ transport is mainly northeastward due to the high contribution of the NAC in the upper layer while CFC transports are southwestward due to the contribution of the EGC in the intermediate layer.

As described previously, the properties are decomposed into three components (Figure 5). The section mean values are ascribed to the barotropic component: $26 \mu \mathrm{mol} \mathrm{kg}^{-1}$ for $\mathrm{C}_{\text {ANT }}$, and 1.95 and 0.99 pmol $\mathrm{kg}^{-1}$ for CFC-11 and -12, respectively. The area weighted vertical profiles of each property are shown in Figure $5 \mathrm{a}, \mathrm{b} \& \mathrm{c}$. Vertical deviations of this profile from the section mean correspond to the baroclinic component of the properties. The horizontal component of each property is calculated as the anomaly of its distribution from its area weighted vertical profile. The anomalies show the horizontal or along-section differences in the tracer distributions (Figure $5 d$, e \& f).

The A25 section crosses an area of newly formed deep water masses. Thus, is not surprising to find significant $\mathrm{C}_{\mathrm{ANT}}$ and CFCs signals down to 3200 dbar (Figure $5 a, b$ \& c). Below 3200 dbar a steep gradient separates the upper "contaminated" waters from IAP (Iberian Abyssal Plain) deep waters with negligible tracer concentrations. The section mean vertical CFC profiles are similar in shape to each other, with higher than the section mean values in the upper water and lower values below about $2000 \mathrm{dbar}$.

Clearly, $C_{A N T}$ anomalies (Figure $5 d$ ) differ from those of CFC (Figure $5 e$ \& f). Positive $C_{\text {ANT }}$ anomalies (values higher than the area weighted vertical profile) are found in the upper layer south of the NAC and around 2000 dbar associated with LSW. Negative anomalies are associated with SAIW in the upper layer north of the NAC and LSW in the Iberian Basin. CFC anomalies (Figure 5e \& f) present a north-south distribution, upper cold waters (positive anomalies) and recently formed LSW and the overflows north of the NAC dissolve more CFC. Please recall Figure 2 for the acronyms and water mass distributions along the WOCE A25 section.

The baroclinic or overturning circulation drives a northeastward flow of $14.8 \mathrm{~Sv}$ in the upper 1000 dbar (Figure 6a), mainly ascribed to the NAC system, which is compensated by a southwestward flow of $16.5 \mathrm{~Sv}$ at intermediate levels. The horizontally integrated volume transport accumulated from zero at the east (Figure 6e) shows the two main horizontal currents across the section, the NAC and the EGC, transporting 28.4 Sv and $25.4 \mathrm{~Sv}$, respectively.

When the volume fluxes components (Figure $6 a \&$ e) are associated with the corresponding baroclinic and horizontal anomalies (Figure 5), the tracer transports are obtained. Similar 
overturning profiles are calculated for the three tracers (Figure $6 b, c \& d$ ) while differences emerge in the horizontal transports (Figure $6 f, g \& h$ ). The overturning circulation within the North Atlantic introduces both $\mathrm{C}_{\mathrm{ANT}}$ and CFC in the upper and deep layers, this is because higher than the section mean $\mathrm{C}_{\mathrm{ANT}}$ and CFC waters are transported northeastward and lower than the section mean $\mathrm{C}_{\mathrm{ANT}}$ and CFC waters are transported southwestward, leading both to a net northeastward transport. The EGC stands out as the main contributor to the southwestward CFC horizotal transports, while the main contributor to the horizontal $\mathrm{C}_{\mathrm{ANT}}$ transport is the NAC.

Figure 7 shows a summary of the mechanisms: the baroclinic or overturning and the horizontal transports for $\mathrm{CFC}$ and $\mathrm{C}_{\mathrm{ANT}}$. The horizontal circulation drives southwestward fluxes for the three tracers in the upper and deep layers. Upper waters north of the NAC, especially in the EGC, have higher CFC (lower $\mathrm{C}_{\mathrm{ANT}}$ ) concentrations than waters at the same vertical layer south of the NAC, these concentration anomalies when combined with the volume flux finally yield a negative transport in the upper layer. In the deep layer the horizontal negative transport is dominated by positive tracer anomalies (both CFC and $\mathrm{C}_{\mathrm{ANT}}$ ) north of the NAC where the flux is southwestward. Basically, the overturning circulation introduces tracers into the subpolar North Atlantic mainly within the upper layer and NAC region, and the horizontal or gyre circulation carries them into the temperate North Atlantic, mainly within the upper layer and the EGC region.

\section{Discussion}

Globally, $\mathrm{C}_{\mathrm{ANT}}$ is mainly taken up and accumulated in the tropical and subtropical regions (Sabine et al., 2004; Mikaloff-Fletcher et al., 2006), respectively, while CFCs are taken up and accumulated in high latitudes (Dutay et al., 2002; Willey et al., 2004). Looking at the global 1994 CFC (Willey et al., 2004) and $C_{\text {ANT }}$ (Sabine et al., 2004) inventories similarities arise: $82 \%$ of the CFC-11 inventory is found at depths shallower than $1000 \mathrm{dbar}$ and $93 \%$ of the $\mathrm{C}_{\mathrm{ANT}}$ accumulation is found shallower than $1500 \mathrm{dbar}$. Additionally, two regions present a clear relation: the North Atlantic and the circumpolar Subantarctic Front (north of about $50^{\circ} \mathrm{S}$ ). These two areas correspond to high ventilation areas, where deep (North Atlantic Deep Water) and intermediate (Subantarctic Mode Water/ Antarctic Intermediate Water) waters are formed, respectively. Despite this, the most striking difference occurs in the Southern Ocean, the area around $50^{\circ} \mathrm{S}$ is an area of prominent CFC-11 accumulation (Willey et al., 2004), but where only $5 \%$ of the total $C_{A N T}$ inventory is found according to Sabine et al. (2004). In this sense, recent studies questioned the $C_{A N T}$ estimation method at these latitudes (e.g., LoMonaco et al., 2005).

Divergences in the uptake and accumulation of $\mathrm{CFC}$ and $\mathrm{C}_{\mathrm{ANT}}$ within the ocean result from: 1) the different atmospheric evolutions (anthropogenic $\mathrm{CO}_{2}$ has been present in the atmosphere for about 200 years while CFC-11 and CFC-12 for about 50 years), 2) different relationships with temperature (CFC solubility increases with low temperature, while warm waters tend to take up more $\mathrm{C}_{\mathrm{ANT}}$ ), and 3) different gas exchange residence times (the $\mathrm{CO}_{2}$ Schmidt number is smaller than the CFC's one, i.e., the $\mathrm{CO}_{2}$ gas exchange would be faster for $\mathrm{CO}_{2}$, but the ocean buffer capacity, or Revelle factor ${ }^{1}$, greatly increases the equilibration time of the upper mixed layer for $\mathrm{CO}_{2}$ compared to CFC).

The results presented here reveal further evidence for the different behaviour of the manmade tracers, CFC and $\mathrm{C}_{\mathrm{ANT}}$, in the ocean: their opposite advective transports in the subpolar North Atlantic point to different routes of uptake and accumulation despite their general high accumulation in this region. The air-sea CFC uptake north of the NAC stands out (Dutay et al., 2002) as a consequence of the higher solubility (low temperature) and wind stress (Risien and Chelton, 2008) in this region compared to the warmer and calmer area south of it. South of the NAC, contrary to CFC, more $C_{A N T}$ is dissolved due to the lower Revelle factor (higher temperature). Along the WOCE A25 section the main $\mathrm{C}_{\text {ANT }}$ distribution differences are found vertically between upper and deep waters, in the case of CFC main differences are found horizontally, north and south of the NAC. Consequently, the non-linear 
correlation between the $\mathrm{C}_{\mathrm{ANT}}$ and CFC distributions is mainly due to the different $\mathrm{C}_{\mathrm{ANT}}$ and CFC relation with temperature and air-sea equilibration time. Both lead to the uncoupled behaviour in their transports. The $\mathrm{C}_{\mathrm{ANT}}$ transport is controlled by the overturning circulation while the CFC transport is driven by the large-scale gyre circulation.

\section{Acknowledgements}

M.A. was funded by grant ORCASEX (RYC-2006-001836), program "Ramón y Cajal" from the Spanish Ministry of Science and Technology. C.G. was funded by CNES (Ifremer, France).

\section{References}

Álvarez, M., A.F. Ríos, F.F. Pérez, H.L. Bryden and G. Rosón (2003), Transports and budgets of total inorganic carbon in the Subpolar and Temperate North Atlantic, Global Biogeochem. Cycles, 17(1), 1002, doi:10.1029/2002GB001881.

Álvarez, M., F. F. Pérez, H. Bryden, and A. F. Ríos (2004), Physical and biogeochemical transports structure in the North Atlantic subpolar gyre, J. Geophys. Res., 109, C03027, doi:10.1029/2003JC002015.

Álvarez, M., H.L. Bryden, F.F. Pérez, A.F. Ríos and G. Rosón (2002), Physical and biogeochemical fluxes and net budgets in the Subpolar and Temperate North Atlantic, J. Mar. Res., 60, 191-226.

Anderson, L.A. and J.L. Sarmiento (1994), Redfield ratios of remineralization determined by nutrient data analysis, Global Biogeochem. Cycles, 8, 65-80.

Bacon, S. (1998), RRS Discovery cruise 230, 07-Aug-17 Sep 1997. Two hydrographic sections across the boundaries of the Subpolar Gyre: FOUREX. Southampton Oceanography Centre Cruise Report, No 16, 104 pp.

Boswell, S. M. and D. Smythe-Wright (1996), Dual-detector system for the shipboard analysis of halocarbons in sea-water and air for oceanographic tracer studies, Analyst, 121, 505-509.

Broecker, W. S., T. Takahashi, H. J. Simpson, and T. H. Peng (1979), Fate of fossil fuel carbon dioxide and the global carbon budget, Science, 206, 409- 418, doi:10.1126/science.206.4417.409.

Bullister, J. L. and R. F Weiss (1988), Determination of CC13F and CC12F2 seawater and air, Deep-Sea Res., 25, 839-853.

Dutay, J.-C. et al. (2002), Evaluation of ocean model ventilation with CFC-11: comparison of 13 global ocean models, Ocean Modelling, 4, 89-120.

England, M.H. and E. Maier-Reimer (2001), Using chemical tracers to assess ocean models, Rev. Geophys. 39, 29-70.

Gammon, R., J. Cline, and D. Wisegarver (1982), Chlorofluoromethanes in the Northeast Pacific Ocean: Measured Vertical Distributions and Application as Transient Tracers of Upper Ocean Mixing, J. Geophys. Res., 87(C12), 9441-9454.

Gruber, N., J.L. Sarmiento, and T.F. Stocker (1996), An improved method for detecting anthropogenic CO2 in the oceans, Global Biogeochem. Cycles, 10, 809-837.

Hall, T.M., T.W.N. Haine, and D.W. Waugh (2002), Inferring the concentration of anthropogenic carbon in the ocean from tracers, Global Biogeochem. Cycles, 16, 10.1029/2001GB001835.

Keeling, C.D., ad B. Bolin (1962), The simultaneous use of chemical tracers in oceanic studies, Tellus, 19, 566-581.

Körtzinger, A., M. Rhein, and L. Mintrop (1999), Anthropogenic CO2 and CFC in the North Atlantic Ocean, a comparison of mand-made tracers, Geophys. Res. Lett. 26, 2065-2068. 
LeBel, D.A., W.M. Smethie Jr., M. Rhein, D. Kieke, R.A. Fine, J.L. Bullister, D.-H. Min, W. Roether, R. F. Weiss, C. Andrie, D. Smythe-Wright, and E.P. Jones (2008), The formation rate of North Atlantic Deep Water and Eighteen Degree Water calculated from CFC-11 inventories observed during WOCE, Deep-Sea Res. 1, 55(8), 891-910.

Lherminier, P., H. Mercier, C. Gourcuff, M. Alvarez, S. Bacon, and C. Kermabon (2007), Transports across the 2002 Greenland-Portugal Ovide section and comparison with 1997, J. Geophys. Res., 112, C07003, doi:10.1029/2006JC003716.

Lo Monaco C., C. Goyet, N. Metzl, A. Poisson, and F. Touratier (2005), Distribution and inventory of anthropogenic $\mathrm{CO}_{2}$ in the Southern Ocean: comparison of three data-based methods, J. Geophs. Res., 110, doi: 10.1029/2004JC002571.

Macdonald, A.M., M.O. Baringer, R. Wanninkhof, K. Lee, and D.W.R. Wallace (2003), A 1998-1992 comparison of inorganic carbon and its transport across $24.5^{\circ} \mathrm{N}$ in the Atlantic, Deep-Sea Res. II, 50, 3041-3064.

McNeil, B.I., R.J. Matear, R.M. Key,J.L. Bullister and J.L. Sarmiento (2003), Anthropogenic $\mathrm{CO}_{2}$ uptake by the ocean based on the global chlorofluorocarbon data set, Science, 299, 235-239.

Mehrbach, C., C. H. Culberson, J. E. Hawley, and R. M. Pytkowicz (1973), Measurements of the apparent dissociation constant of carbonic acid in seawater at atmospheric pressure, Limnol. Oceangr., 8, 897-907.

Mikaloff Fletcher, S. E., et al. (2006), Inverse estimates of anthropogenic CO2 uptake, transport, and storage by the ocean, Global Biogeochem. Cycles, 20, GB2002, doi:10.1029/ 2005 GB002530.

Neftel, A., H. Friedli, E. Moor, H. Lötscher, H. Oeschger, U. Siegenthaler and B. Stauffer. (1994), Historical $\mathrm{CO}_{2}$ record from the Siple station ice core, in Trends'93: A compendium of Data on Global Change, edited by T. Boden, D. Kaiser, R. Sepanski, and F. Stoss, Rep. ORNL/CDIAC-65 pp.11-14, Carbon Dioxide Inf. Anal. Cent., Oak Ridge Nath. Lab., Oak Ridge, Tenn.

Pérez, F.F., M. Álvarez, and A.F. Ríos (2002), Improvements on the back-calculation technique for estimating anthropogenic $\mathrm{CO}_{2}$, Deep-Sea Res. I, 49, 859-875.

Pickart, R. S., F. Straneo, and G. W. K. Moore (2003), Is Labrador Sea Water formed in the Irminger basin?, Deep Sea Res., Part I, 50, 23- 52.

Revelle, R., and H. E. Suess (1957), Carbon dioxide exchange between atmosphere and ocean and the question of an increase of atmospheric $\mathrm{CO}_{2}$ during the past decades, Tellus, $9,18-27$.

Rhein, M., J. Fischer, W.M. Smethie, D. Smythe-Wright, R.F. Weiss, C. Mertens, D.-H. Min, U. Fleischmann and A. Putzka (2002), Labrador Sea water: pathways, CFC inventory, and formation rates, J. Phys. Oceanogr. 32, 648-665.

Rosón, G., A.F. Rios, A. Lavín, H.L. Bryden, and F.F. Pérez (2002), Carbon distribution, fluxes and budgets in the subtropical North Atlantic, J. Geophys. Res., 108, doi:10.1029/1999JC000047.

Sabine, C.L. and Coauthors (2004), The oceanic sink for anthropogenic $\mathrm{CO}_{2}$, Science 305, 367-371.

Smethie, W. M., Jr. and R. A. Fine (2001), Rates of North Atlantic Deep Water formation calculated from chlorofluorocarbon inventories, Deep-Sea Res. I 48, 189-215.

Tanhua, T., A. Biastoch, A. Körtzinger, H. Lüger, C. Böning, and D. W. R. Wallace (2006), Changes of anthropogenic $\mathrm{CO}_{2}$ and CFC in the North Atlantic between 1981 and 2004, Global Biogeochem. Cycles, 20, GB4017.

Tanhua, T., D. W. Waugh, and D. W. R. Wallace (2008), Use of SF6 to estimate anthropogenic $\mathrm{CO} 2$ in the upper ocean, J. Geophys. Res., 113, C04037, doi:10.1029/2007JC004416.

Tanhua, T., E. P. Jones, E. Jeansson, S. Jutterström, W. M. Smethie Jr., D. W. R. Wallace, and L. G. Anderson (2009), Ventilation of the Arctic Ocean: Mean ages and inventories of anthropogenic $\mathrm{CO}_{2}$ and CFC-11, J. Geophys. Res., 114, 001002 , doi:10.1029/2008JC004868.

Thomas, H. and M.H. England (2002), Different oceanic features of anthropogenic $\mathrm{CO}_{2}$ and CFC, Naturwissenschaften 89, 399-403. 
Willey, D. A., R. A. Fine, R. E. Sonnerup, J. L. Bullister, W. M. Smethie Jr., and M. J. Warner (2004), Global oceanic chlorofluorocarbon inventory, Geophys. Res. Lett., 31, L01303, doi:10.1029/2003GL018816.

\section{Tables}

Table 1. Mechanisms of the tracer transports across the A25 section. Units are $\mathrm{kmol} \mathrm{s}^{-1}\left(10^{3}\right.$ $\mathrm{mol} \mathrm{s}^{-1}$ ) and $\mathrm{mol} \mathrm{s}^{-1}$ for $\mathrm{C}_{\mathrm{ANT}}$ and CFC transports, respectively.

\begin{tabular}{|l|c|c|c|c||}
\hline & Barotropic & Baroclinic & Horizontal & Net \\
\hline C $_{\text {ANT }} \mathrm{kmol} \mathrm{s}^{-1}$ & -26 & 346 & -238 & $82 \pm 39$ \\
\hline CFC-11 mol s & 1.1 & 19.9 & -45.2 & $-24.2 \pm 4$ \\
\hline CFC-12 $\mathrm{mol} \mathrm{s}^{-1}$ & 0.6 & 10.8 & -22.4 & $-10.8 \pm 2$ \\
\hline
\end{tabular}

\section{Figures}

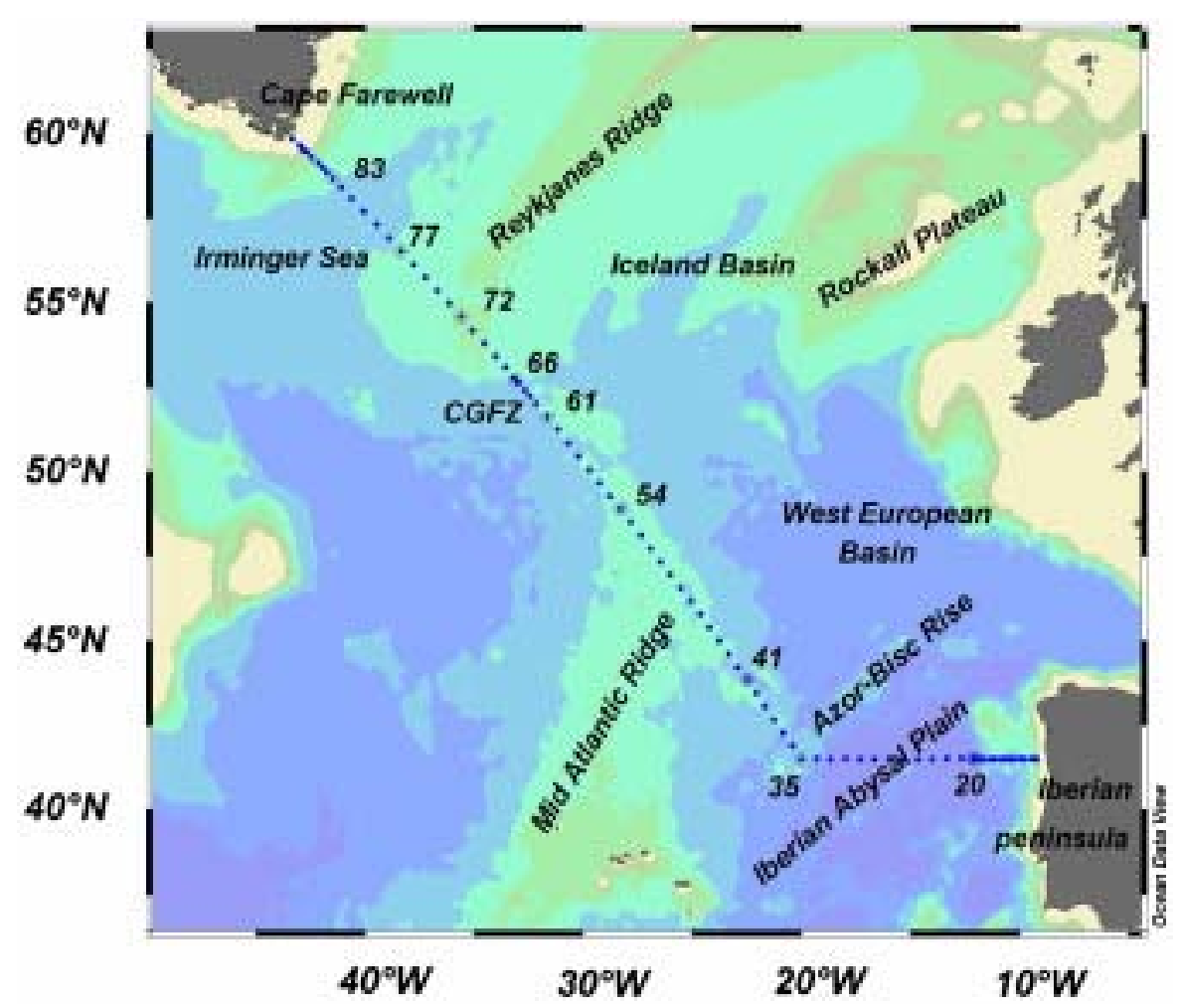

Fig. 1. Station locations along the Vigo-Cape Farewell, WOCE A25 section. See Figure 2 for acronyms. 
a

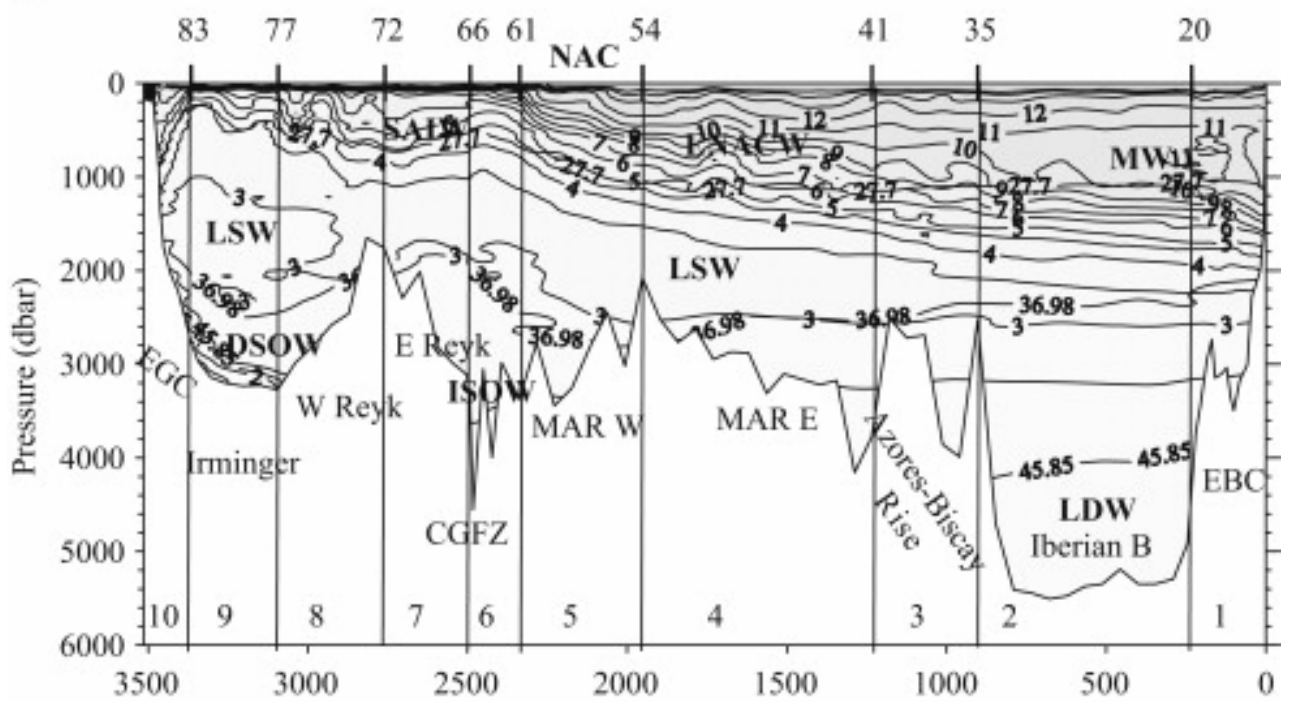

b

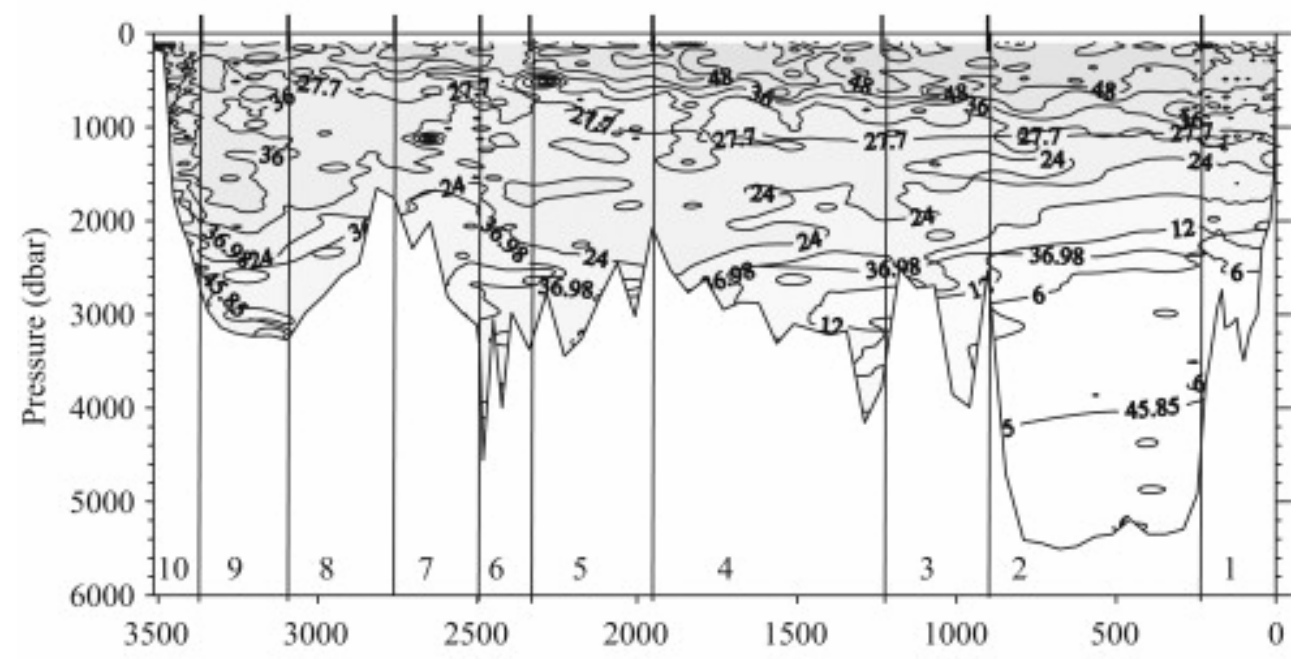

C

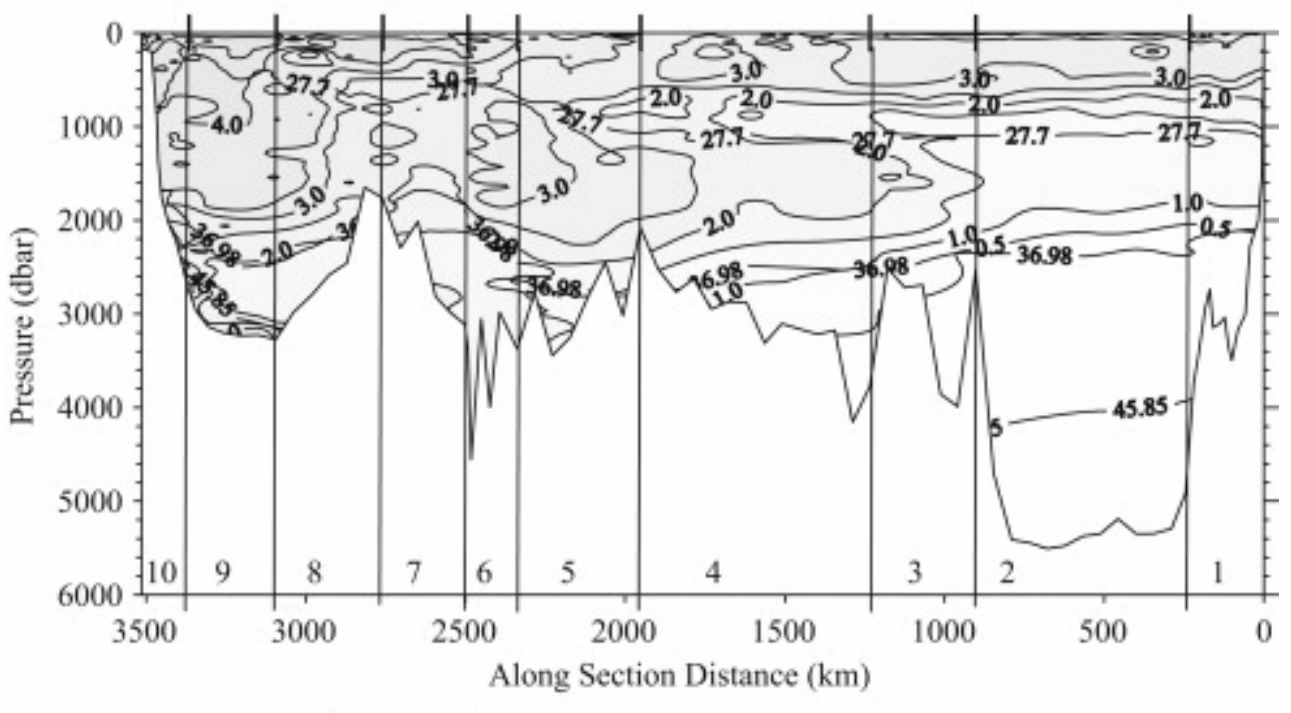

$<$ Northwestwards

Fig. 2. Vertical distributions along the $A 25$ section of (a) potential temperature $\left({ }^{\circ} \mathrm{C}\right)$, (b) anthropogenic carbon $\left(\mu \mathrm{mol} \mathrm{kg}{ }^{-1}\right)$, and (c) CFC-11 $\left(\mathrm{pmol} \mathrm{kg}^{-1}\right)$. The section is divided in ten regions. Density layers are from the surface to $\sigma_{\theta}<27.7, \sigma_{\theta} \geq 27.7$ to $\sigma_{2}<36.98, \sigma_{2} \geq 36.98$ to $\sigma_{4}<45.85$, and $\sigma_{4} \geq 45.85$ denominated as upper, intermediate, deep, and bottom, respectively. EBC, Eastern Boundary Current; Iberian B, Iberian Basin; Azor-Bisc Rise, 
Azores-Biscay Rise; MAR, MidAtlantic Ridge, E, East and W, West; CGFZ, Charlie-Gibbs Fracture Zone; Reyk, Reykjanes Ridge, E, East and W, West; Irminger, Irminger Sea; EGC, East Greenland Current. ENACW, Eastern North Atlantic Central Water; SAIW, SubAntarctic Intermediate Water; LSW, Labrador Sea Water; MW, Mediterranean Water; ISOW, IcelandScotland Overflow Water; DSOW, Denmark Strait Overflow Water; LDW, Lower Deep Water.

a

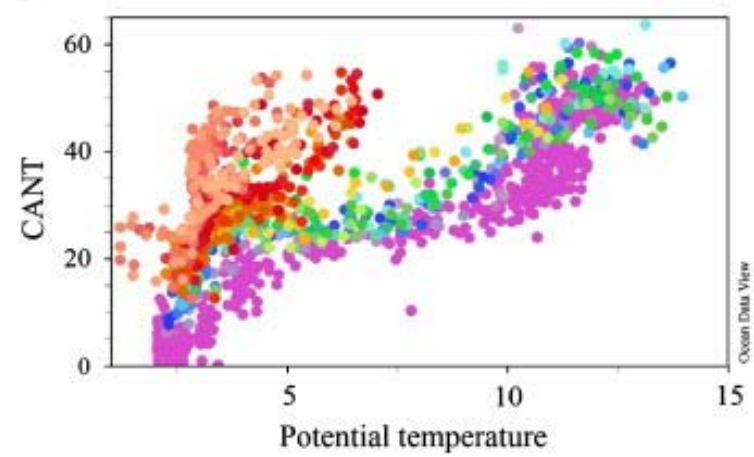

b

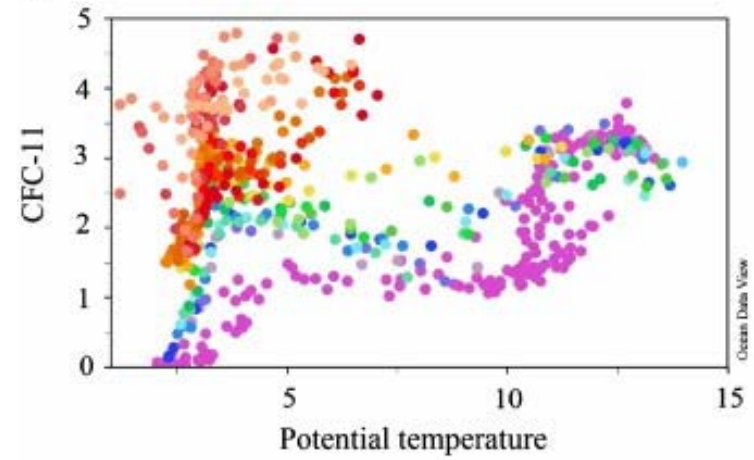

C

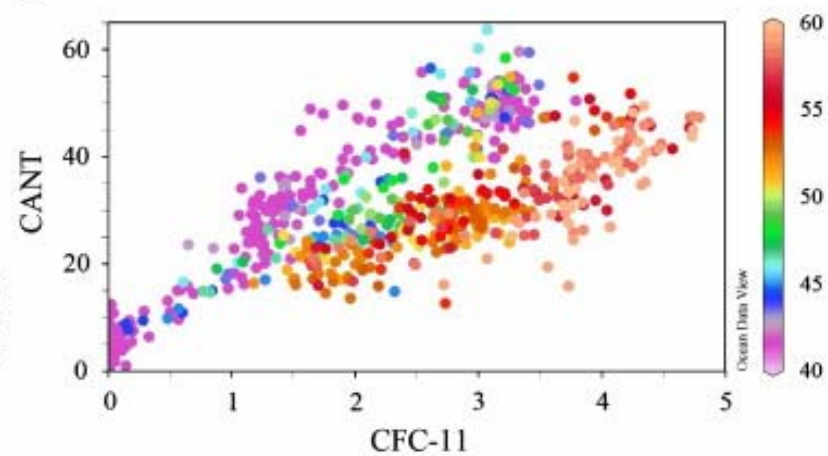

$d$

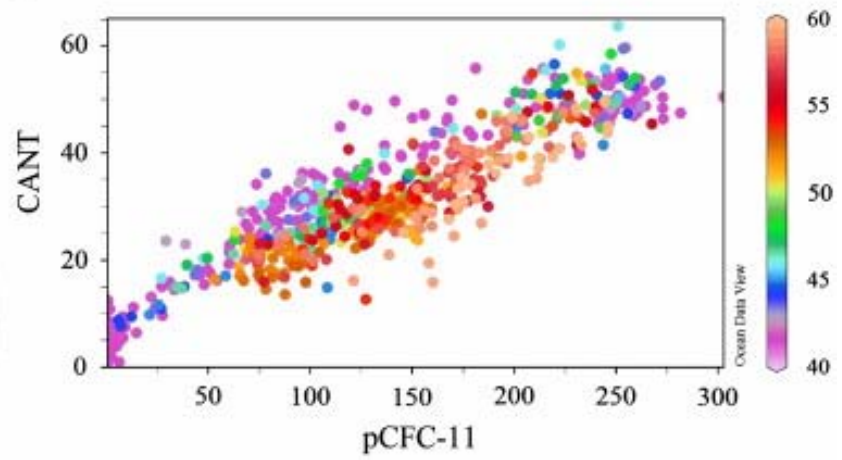

Fig. 3. (a) $\mathrm{C}_{\mathrm{ANT}}\left(\mu \mathrm{mol} \mathrm{kg}{ }^{-1}\right.$ ) and (b) CFC-11 (pmol kg ${ }^{-1}$ ) versus potential temperature $\left({ }^{\circ} \mathrm{C}\right)$; (c) $\mathrm{C}_{\mathrm{ANT}}$ versus CFC-11 and (d) $\mathrm{C}_{\mathrm{ANT}}$ versus pCFC-11 (pptv) for samples below 150 meters along the WOCE A25 section. The colour scale corresponds to the latitude of the sample. 
a

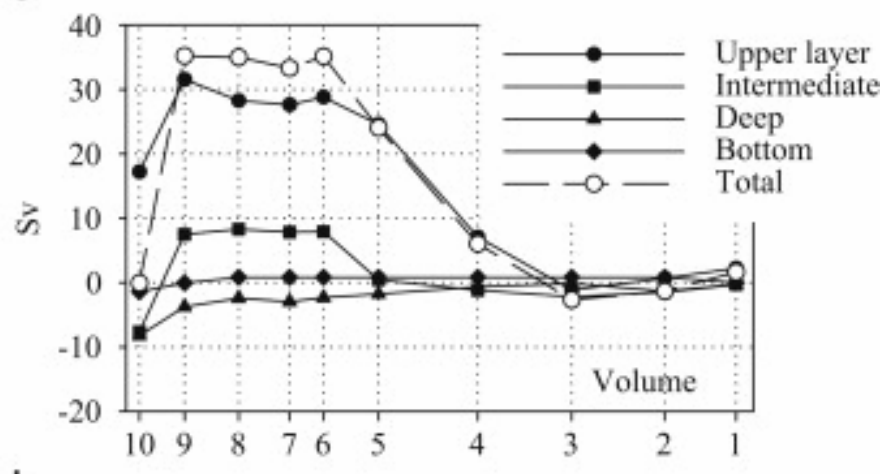

b

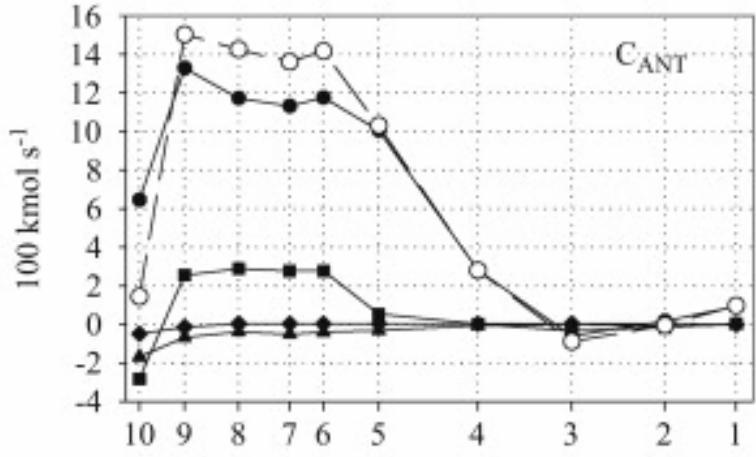

C

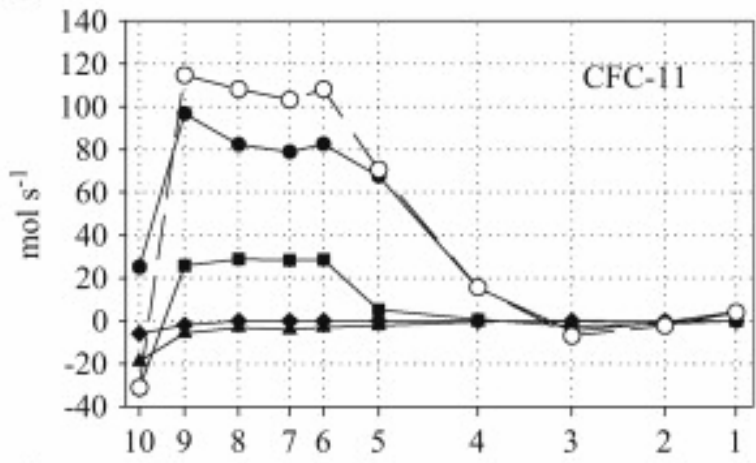

d

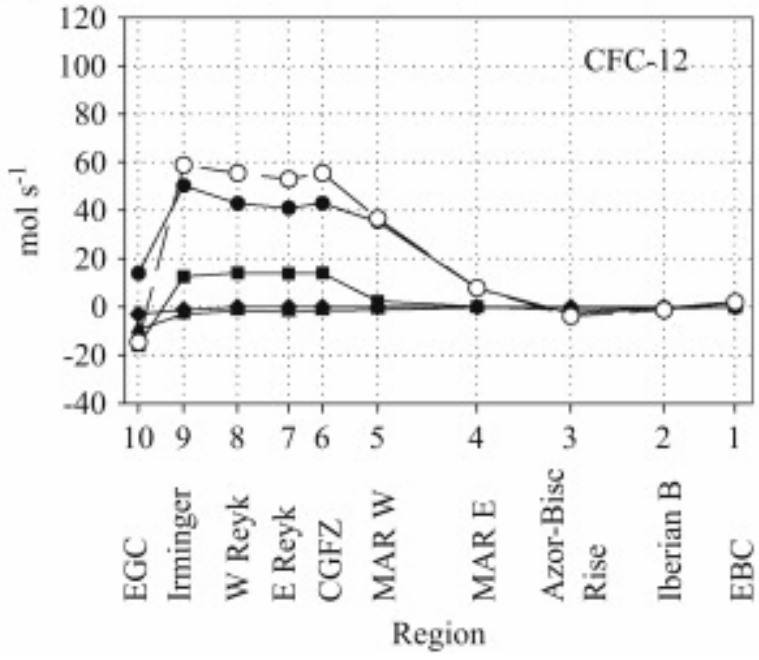

Fig. 4. Regional and vertical net transports across the $A 25$ section accumulated from Vigo (right end) for (a) volume, (b) $C_{\text {ANT }}$, (c) CFC-11, (d) CFC-12. Units are Sv (1 Sv $\left.=10^{6} \mathrm{~m}^{3} \mathrm{~s}^{-1}\right)$, $\mathrm{kmol} \mathrm{s}^{-1}\left(1000 \mathrm{~mol} \mathrm{~s}^{-1}\right)$ and mol s${ }^{-1}$. Regions and density intervals are as in Figure 2a. Positive (negative) values indicate a transport northeastward (southwestward) of the section. 
a

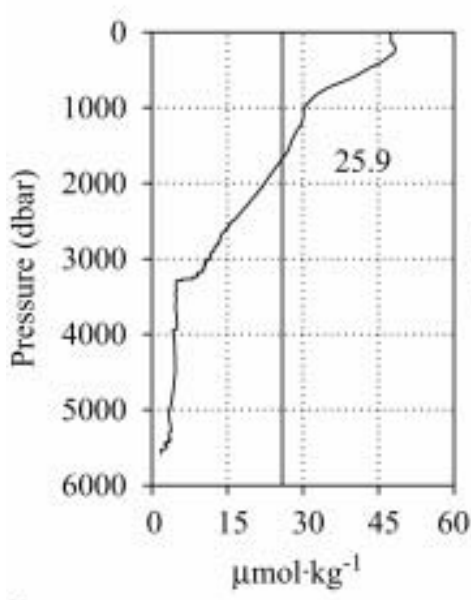

b

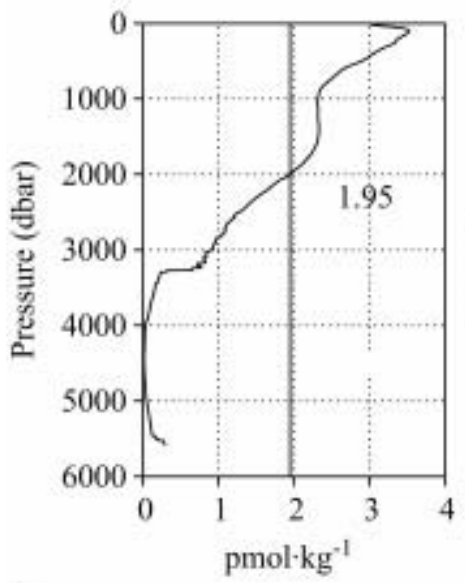

C

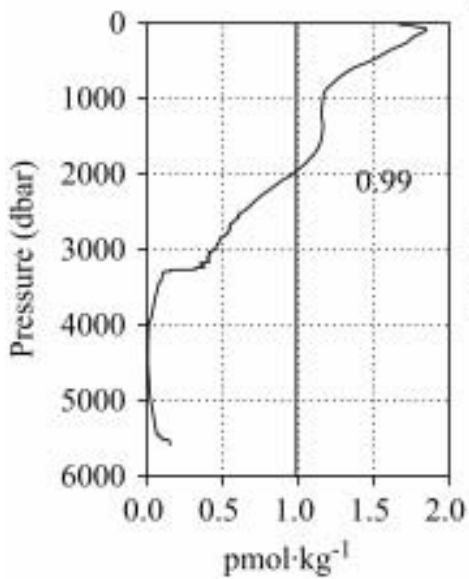

e

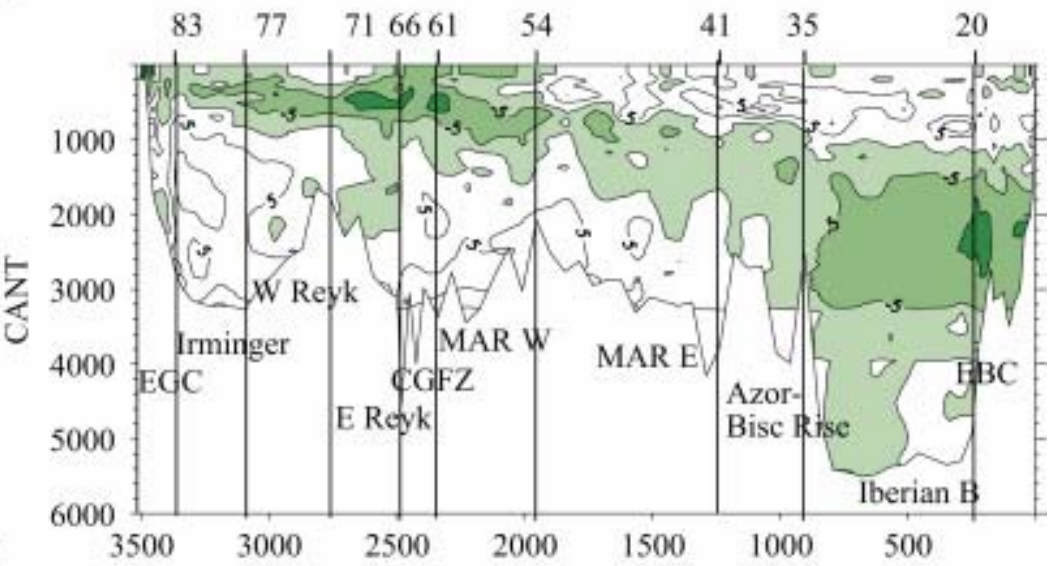

f

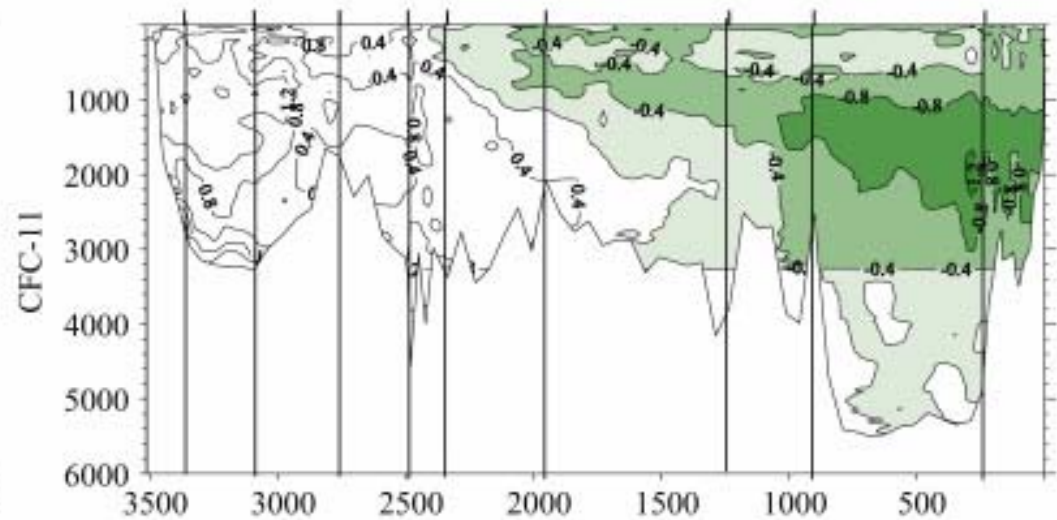

g

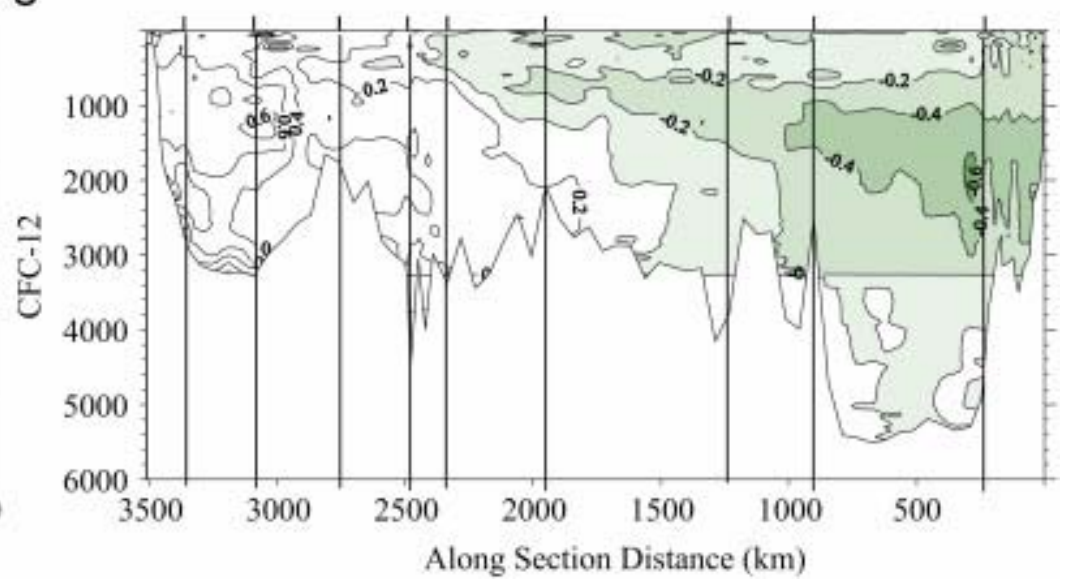

Fig.5. WOCE A25 mean value ( $\bar{C}$ ) and profile (a to $\mathrm{c}$ ) for each tracer, and vertical distribution ( $d$ to $f$ ) of the tracer anomalies $\left(C^{\prime}(x, z)\right)$ along the section. The baroclinic profile of each property $(C<z>)$ is the deviation of the section profile from the mean value as a function of depth. The upper axis in Figure $5 d$ to f shows station positions. Vertical lines mark regions as in Figure $2 \mathrm{a}$. 
a

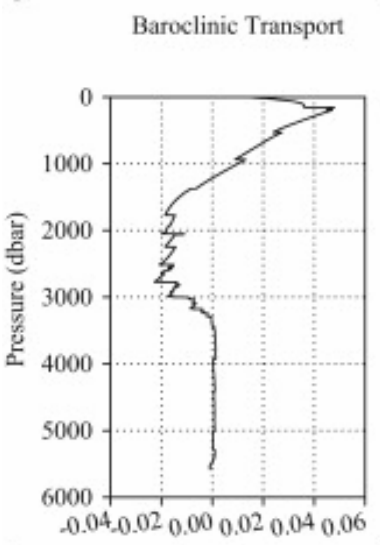

b

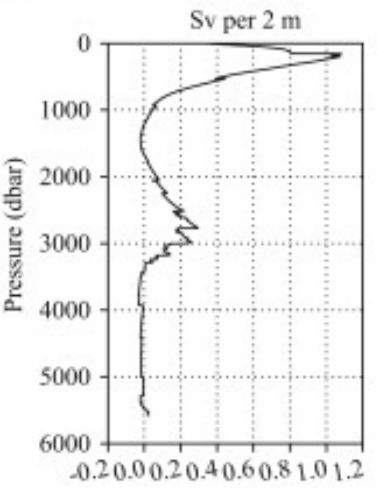

C

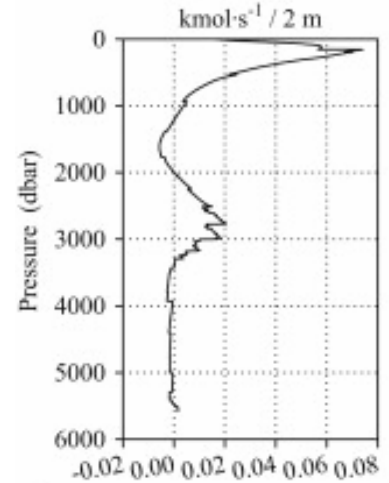

d

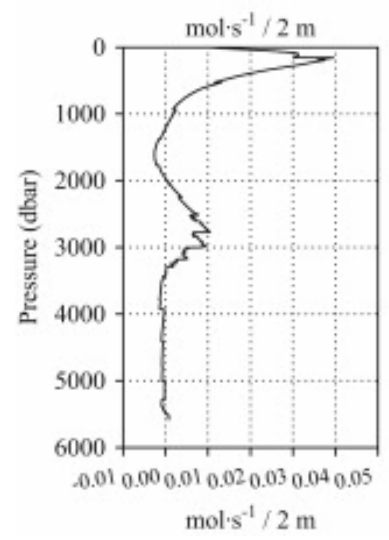

e

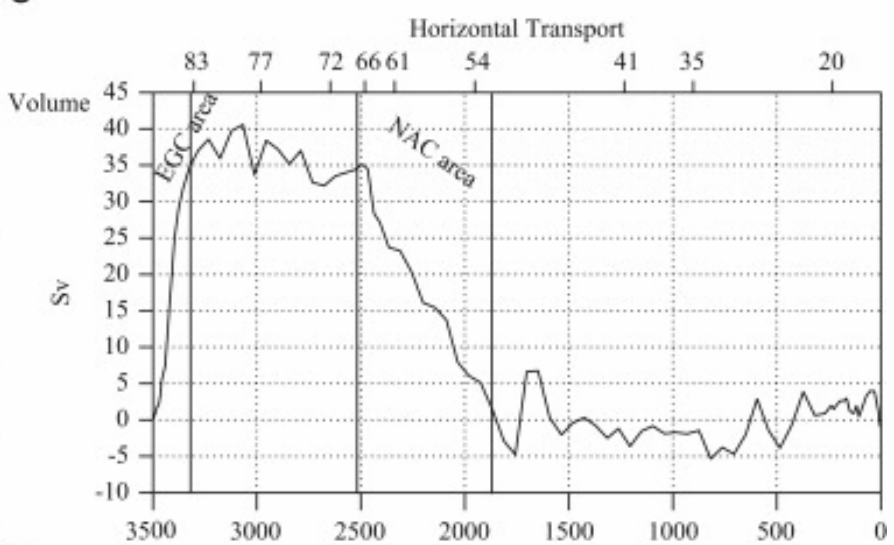

f

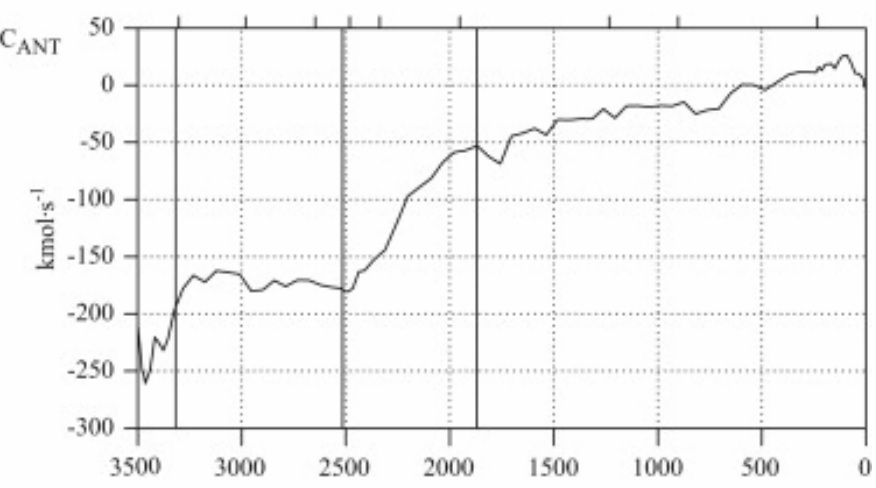

g

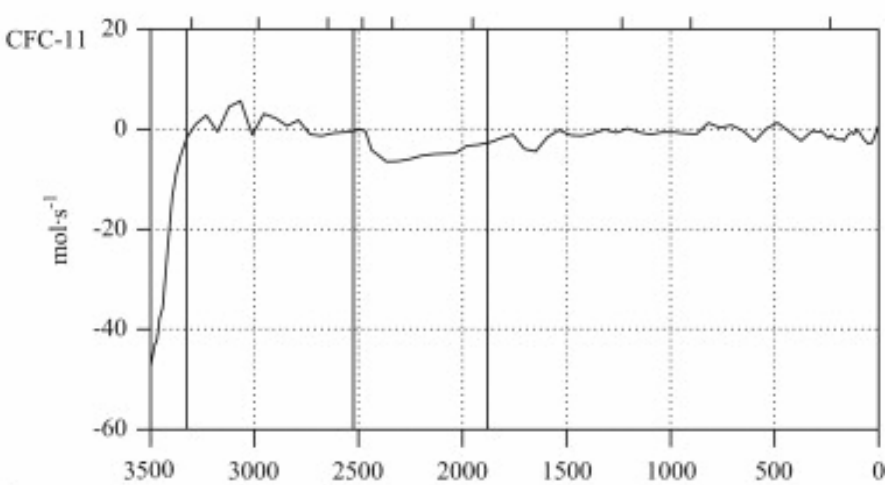

h

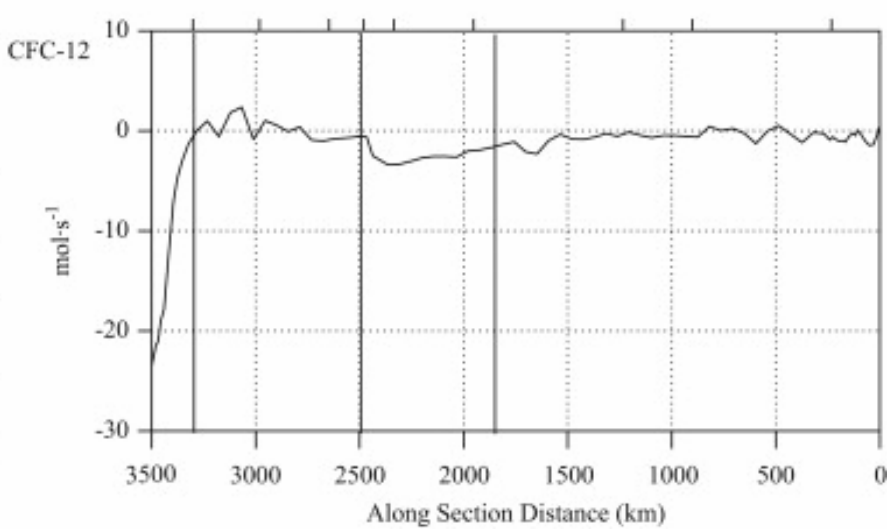

Fig.6. Baroclinic (a to d) and horizontal (e to h) components of the volume, $\mathrm{C}_{\mathrm{ANT}}$ and CFC transports across the WOCE A25 section. The horizontal transport is accumulated from zero at Vigo. The upper axis in Figure $6 e$ to $\mathrm{h}$ shows station positions. Positive (negative) values indicate a transport northeastward (southwestward) of the section. 

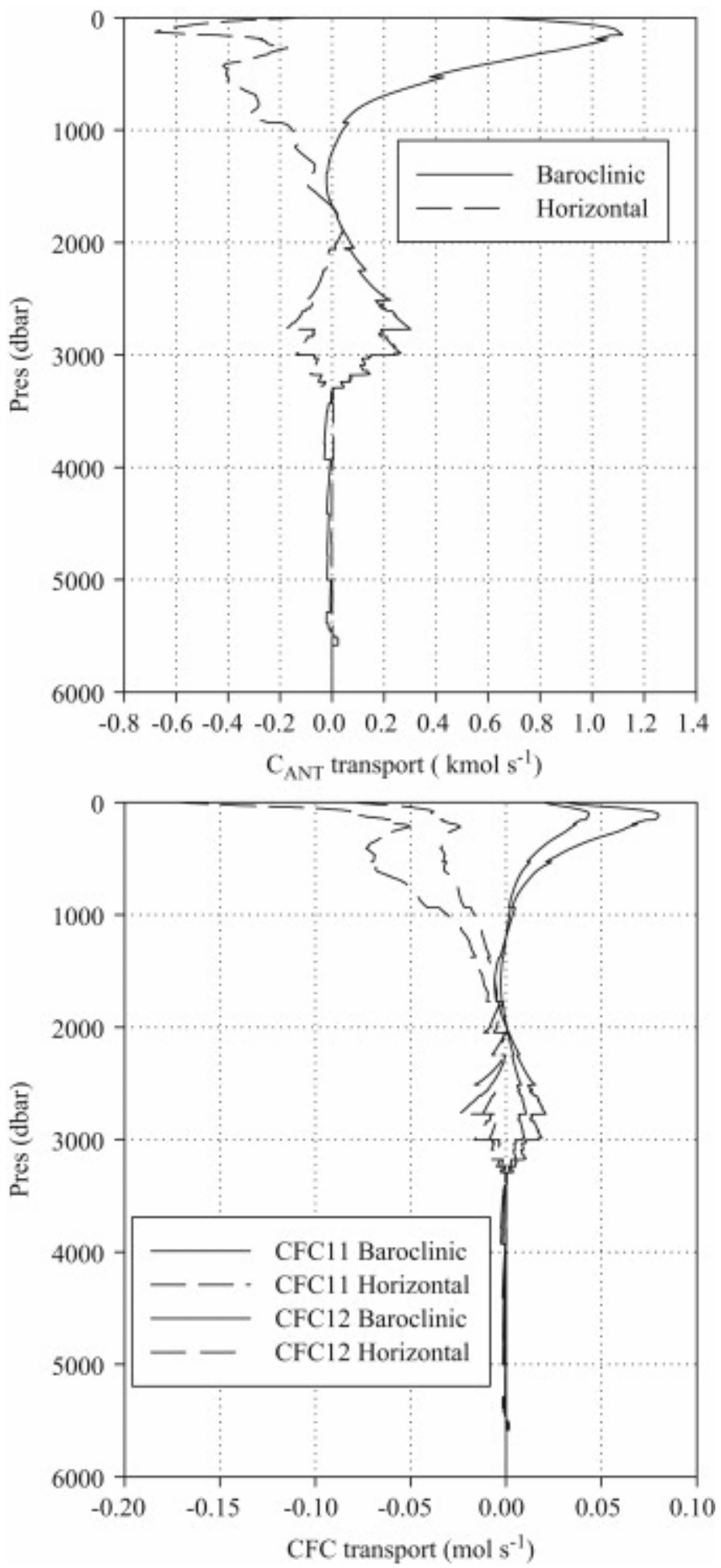

Fig. 7. Baroclinic and horizontal $\mathrm{C}_{\mathrm{ANT}}, \mathrm{CFC}-11$ and $\mathrm{CFC}-12$ transports across the $\mathrm{A} 25$ section. Positive (negative) values indicate a transport northeastward (southwestward) of the section. 